\title{
Tobaksdyrkning i Aabenraa i det 18. Aarhundrede.
}

\section{Raadmand Cornelius Cornelsen, der i 1780-90-erne drev Tobaksavl paa „Gammeldama. \\ Af Carl E. Johnsen.}

I Tiden omkring sidste Halvdel af det 18. Aarhundrede, da Transportforholdene mellem Landene endnu ikke var særlig godt udviklede, var Priserne paa udenlandsk Tobak som Følge deraf meget høje. Naar dette Nydelsesmiddel derfor skulde indføres fra Udlandet, ligesom Kaffe og Sukker, var det kun de mere velstillede Folk, der kunde tillade sig den Luksus at nyde god udenlandsk Tobak i større Kvantiteter. Da Brugen af Tobak tog til med rivende Fart indenfor alle Befolkningsklasser, henledtes Tanken snart paa Muligheden af selv at sætte Dyrkning af Tobak i Gang her i Landet. Begunstiget af den Handels- og Erhvervspolitik, som Regeringen dengang drev, blev Planen ført ud i Virkeligheden flere Steder i Danmark. Der anlagdes saaledes Tobaksplantager ved København, Køge, Stubbekøbing, Aarhus, Viborg, Fredericia og Aabenraa.

Den Mand, der har Aren af at have indført Avlen af Tobak i Sønderjylland, var Tobakshandler Corneli us Cornelsen i Aabenraa. Han var en meget virksom og paa flere Omraader betydelig Mand, der nød stor Anseelse indenfor Byens Borgerskab. Han var i en Aarrække Raadmand. Det er let forstaaeligt, at Cornelsen, der var en foretagsom og fremskridtsivrig Mand, har kunnet faa den Tanke 
ikke alene at ville salge men ogsaa selv dyrke og tilberede Tobakken. Raamaterialet var efter Datidens Forhold dyrt, og af den Grund havde Tobaksdyrkningen taget Fart rundt om i Europa, idet man derigennem vilde gøre sig saa meget som muligt uafhængig af de amerikanske og asiatiske Tobaksavlere.

Der udkom i 1770-erne det ene Skrift efter det andet, som gav Anvisning paa Fremgangsmaaden ved Tobaksdyrkning, og netop i disse Aar, hvor Cornelsen maa have syslet med Planerne om at anlægge en Tobaksplantage, udkom der en tysk Bog, som han sikkert har læst: "Unterricht zum Anbau des Tabaks, von Korge, Breslau, 1775«, og i 1779, det Aar, hvor Cornelsen for forste Gang saaede Tobaksfrø i den aabenraaske Jordbund, udkom i Darmstadt "Neue und vollständige Abhandlung vom Tabaksbau etc.« af Barkhaus. Foruden fra Tyskland har Cornelsen imidlertid ogsaa modtaget Impulser fra engelsk Side. Han havde nemlig opholdt sig i nogen Tid i England, hvor Tobaksindustrien allerede da havde opnaaet en høj Udvikling, og det er rimeligvis fra England, han har hentet flere af de Erfaringer, han senere skulde komme til at frugtbargøre under Arbejdet i sin Tobaksplantage ved Aabenraa.

For Cornelsen har Anlæget af en Tobaksplantage sikkert - foruden naturligvis at være et okonomisk Spørgsmaal - været et patriotisk Foretagende. Det laa i Tiden, at den indenlandske Industri skulde ophjælpes, og Bestræbelserne dengang gik ud paa i videst muligt Omfang at fremskaffe Raastoffer til de Fabriksvirksomheder, som da blev startede. Kunde Raastofferne skaffes i ens eget Land, var det selvsagt det allerbedste. Det indsaa Cornelsen og handlede derefter. 
Paa den Tid, henimod Overgangen til det 19. Aarhundrede, indførtes der fra Udlandet til DanmarkNorge aarlig 3-4 Millioner Pd. Tobak. Dersom Tobaksavlen kunde lykkes her i Landet, vilde det derfor faa meget stor økonomisk Betydning. Det københavnske Tobaksspinderlav beskroftigede $i$ disse Aar 4-500 Personer, og sidst i 1790-erne fandtes der i de danske Provinser 114 priviligerede Tobaksskærere og 20 Tobaksfabrikanter. Det var dog kun i Fredericia, at Tobaksavlen i en Aarrække kom til at spille en betydelig Rolle. Her havde ved Aarhundredskiftet 90-100 Familier Udkommet alene ved denne Produktion, som ansloges til 200,000 Pd. om Aaret, og Avlen indbragte Byen aarlig 1(i-18,000 Rdl.

Den Tobaksplantage, som Corn. Cornelsen, vel nok med Fredericia som Forbillede, anlagde ved Aabenraa, kom ikke til at antage det Omfang som Tobaksavlen ved Fredericia, men alligevel blev det en Plantage, der vakte Opmærksomhed over hele Landet. I sin Plan og IIforelse spejlede sig i Cornelsens Virksomhed - naturligvis $i$ det forholdsvis smaa - Datidens, den Ove Høegh Guldbergske Periodes erhvervspolitiske Initiativ.

En Hovedbetingelse for, at Tobaksdyrkningerı skulde lykkes her i Landet var, at der anvendtes det bedste Frø, der kunde skaffes. Der blev $i$ de andre europæiske Lande, hvor man havde taget Tobaksdyrkningen op, brugt baade amerikansk og asiatisk Frø, men til vort ofte ublide Klima betragtede man dengang Tobaksfrøet fra Amerika, nærmere bestemt fra Virginia, som det bedste. Cornelsen skaffede sig derfor Frø fra anerkendte amerikanske Tobaksplantager, og i Aaret 1779 lejede han et Stykke Land, som dengang blev kaldt "Gammeldam» og hørte til de 
saakaldte »kgl. Vorwerksländereien«. Det er sandsynligt, at dette Areal har været beliggende ved den nordlige side af Landevejen, der forer forbi Kirkegaarden og vestpaa. I Følge Traditionen skal der nemlig paa det Areal, der følger umiddelbart efter Kirkegaarden, have ligget en Plantage, hvor der dyrkedes Tobak. Det paagaldende Stykke Land, der tidligere bar Navnet "Humlekobbel", fik siden Navnet "Tobakskobbel" efter Tobaksplantagen.

Cornelsen plantede det amerikanske Fro i Mistbede, og da det havde spiret og var kommet op, blev de smaa Tobaksplanter sat ud i Plantagen, efter at Jorden der forst var blevet passende bearbejdet og tilberedt til Formaalet. Forsoget kronedes med Held. Cornelsen passede sine Planter med Omhu, og i 1780 høstede han de første Tobaksblade. Høsten betegnedes som gunstig, og den forskaffede Cornelsen ikke mindre end 1226 Pund Tobaksblade, der i Kvalitet og Godhed langt overtraf den Tobak, som dyrkedes andre Steder $\mathbf{i}$ Landet. I samtidige Beretninger hedder det endog, at Tobakken fra Plantagen fra "Gammeldam " paa ingen Maade stod tilbage for den udenlandske Raatobak.

Det gode Resultat opmuntrede Cornelsen til for det kommende Aar at tage et nyt Stykke Land ind til Tobaksdyrkning. Atter blomstrede Tobakken i Plantagen paa "Gammeldam", og Cornelsens samtidige har uden Tvivl om Sommeraftenerne i Tiden fra Slutningen af Juli til September, hvor Tobaksplanterne stod i Blomst, lagt deres Aftenspadseretur til "Gammeldam" for at betragte de eksotiske Planter, der trivedes saa godt i den aabenraaske Jordbund, og Cornelsen selv har vel med Stolthed vist sin Tobaks-Ager frem. Maaske har han i sit stille Sind 
haabet, at Tobakken skulde blive det for Aabenraa i Fremtiden som Humlen havde været i de svundne Aarhundreder. Resultaterne i de nærmest følgende Aar var i alt Fald egnet til at give en saadan Tanke Fart. I Aaret 1781 høstede han saaledes 1421 Pund Tobaksblade. Kvaliteten var lige saa god som det foregaaende Aars, og i 1782 naaede Høsten op paa 2000 Pund.

Efter denne lovende Begyndelse har Cornelsen tilsyneladende atter foretaget en Udvidelse af Plantagen. De samtidige Kilder, der omtaler Foretagendet, beretter nemlig, at Høsten i 1783, som blev en Rekordhøst, gav 8,037 Pund Tobaksblade. Denne Tobak, hedder det, novertraf i Godhed langt den Tobak, der ellers avledes her i Landet og lod opstaa Tvivl, om denne Tobak virkelig var vokset i "Gammeldam «."

Det var et bemærkelsesværdigt Fremskridt, der var gjort ved Anlæget af Tobaksplantagen, men det var ikke tilstrækkeligt for virksomt at imødegaa Konkurrencen fra Udlandet. Tilberedningen af Tobaksbladene baade til Røgtobak og Snus stod i Cornelsens Tid paa et temmelig ufuldkomment Standpunkt herhjemme, og som Følge af den bedre Tilberedelse, som Udlandets Fabrikker forstod at give Raatobakken, stod disse fremmede færdige Produkter over Indlandets i Kvalitet.

Paa hin Tid var England det Land, hvor den fineste Røg- og Snustobak fremstilledes, og Cornelsen blev snart klar over, at skulde Tobaksavlen blive en virkelig betydelig Industri, var tekniske Fremskridt efter engelsk Forbillede en Forudsætning. Især gjaldt det om at skaffe sig de Maskiner, der kunde give Tobakken den rigtige Behandling. Cor- 
nelsen stillede sig derfor allerførst den Opgave at konstruere Maskiner, som muliggjorde ham at give Røgtobakken det mengelske Snit o og findele Snustobakken, saaledes at Kvaliteten blev lige saa god som ellers men med mindre Vxgttab.

De Vanskeligheder, der forelaa, bestod væsentlig $j$, at han ikke havde noget Forbillede at gaa efter. Paa den Tid fandtes der nemlig ikke nogen storre Tobaksfabrikker i Danmark. Man hjalp sig med smaa Haandmaskiner. I Malmø fandtes omkring Aar 1800 en Tobaksfabrik, som dreves af Heste, den eneste i sin Slags i hele Sverige. Cornelsen kunde derfor ikke gaa til en Maskinbygger og bestille en Maskine, som han forstod var nødvendig, thi Maskibyggeren havde aldrig tidligere udført et saadant eller et lignende Arbejde. Han gik imidlertid hverken af Vejen for Udgifter eller Anstrengelser, og efter at have overvundet store Vanskeligheder lykkedes det ham at bygge en Tobaksmølle, som blev trukket af en Hest.

Ved sin nye Mølles Hjælp kunde Cornelsen daglig skære 5-600 Pund Røgtobak efter engelsk Metode og af lige saa god Kvalitet som den engelske Tobak. I samme Tid kunde han tilskære og findele 1-200 Pund Snustobak. Til Tobaksmøllens Betjening var to Mand nødvendig. Ved de ellers almindeligt anvendte Haandmøller kunde to Mand kun give 60-70 Pund Røgtobak det engelske Snit eller i samme Tid findele 30-40 Pund Snustobak. Skønt der ved denne sidstnævnte Fremgangsmaade med HaandInstrumenterne kun blev behandlet smaa Mængder, fik Røgtobakken dog ikke det rigtige engelske Snit og tabte derfor i Værdi, medens stort Vægttab gjorde sig gældende ved Behandlingen af Snustobakken. 
Disse Ulemper blev fuldstændig fjernede ved Anvendelsen af Cornelsens Maskine.

Der er crund til at antage, at Cornelsen $i$ den forste Tid maa have raadet over efter Tillen ret betydelige Pengenidler, som har tilladt ham at gennemføre sine Planer uden fremmed Hjælp. Det sandsynligste er vel dog, at han har faaet Statsstotte. I Aaret 1785 vender han sig i alt Fald til Kongen og beder om Understøttelse, der skulde bruges til Indkøb af et større Parti Raatobak, saaledes at han fuldstændig kunde udnytte sin Tobaksmølle. Det var selvfølgelig nødvendigt, at Møllen blev udnyttet helt ud, for at den kunde forrente de til dens Bygning anvendte Pengemidler.

Det ser ud til - efter et af de Dokumenter, der findes i Arkivet i Aabenraa - at han flere Gange har søgt Kongen om Støtte. Det er dog ikke lykkedes mig at faa oplyst, hvorledes Kongen og Regeringen har stillet sig, og om han virkelig har modtaget en saadan Støtte. Sandsynligheden taler for, at Cornelsen en Overgang har faaet okonomisk Hjælp til sit Foretagende. Naar han andrager om Støtte, er det tillige, fordi han ikke kan dyrke saa store Mængder Tobak paa "Gammeldam", som den nye Tobaksmølle kunde forarbejde. Ansøgningerne skal have været bilagt med Prøver af den Raatobak, der hidrorte fra Aabenraa Tobaksplantage og var behandlet i Cornelsens Tobaksmølle. Kvaliteten af denne Tobak, hedder det, skal have maalt sig med de udenlandske Fabrikata i enhver Henseende.

Naar der nu er Adgang til en Oversigt over Tobaksfabrikationen i Aabenraa, dens Omfang, Priser o. s. v., fra denne Tid, skyldes det den Interesse, som Statholderen Prins Carl af Hessen-Cassel nærede for 
Tobaksindustrien, der paa denne Tid havde taget et efter Forholdene betydeligt Opsving i Aabenraa. Formentlig i Begyndelsen af Aaret 1785 bad Statholderen Magistraten i Aabenraa om at tilsende sig detaillerede Oplysninger om Tobaksavlen og Fabrikationen i Aabenraa. Den 13. April 1785 har Magistraten indsamlet de onskede Oplysninger og sender dem til Statholderen. I en Skrivelse, der ledsager Materialet, skriver Magistraten bl. a., at Corn. Cornelsens Virksomhed er den eneste, der fortjener Navnet Tobaksfabrik i Aabenraa. Sidst i 1770-erne var der godt en halv snes smaa Virksomheder i Aabenraa, hvor der forarbejdedes Tobak, medens der var mindst 13-14 Tobakshandlere.

Cornelsen havde selv ifølge de af Magistraten indsamlede Oplysninger $i$ sin. Plantage avlet anselige Mængder Tobak og ved egen Opfindsomhed konstrueret en kostbar Mølle til at skære Tobakken med, og han havde liverken sparet Penge eller Arbejde for at forbedre sin Fabriksvirksomhed.

De Oplysninger, der vedrører Cornelsens Tobaksfabrik, har Cornelsen selv opgivet paa Magistratens Anmodning. Meddelelserne gaar ud paa:

1) at jeg stadig beskæftiger 4 Personer i min Fabrik, undertiden flere.

2) at den nodvendige Raatobak dels dyrkes paa Stedet og dels købes. Den fremmede Tobak omfatter Portorico, Brasil, ungarske, russiske, preussiske og hollandske Tobakker.

3) at Røgtobakken paa min Fabrik ikke alene skæres efter hollandsk, men ogsaa efter engelsk System, og Rulletobakken bliver lige saa godt spundet her som i Holland og England. Snustobakkens Findeling og Tilberedning sker ligeledes paa samme Maade som i de nævnte Lande. 
4) at der siden Juli 1778 til Slutningen af 1782 i Gennemsnit aarlig er solgt 19,212 Pd. Røgtobak her i Landet, 573 Pd. Rapee og til Østersøen 4,833 Pd. I 1783-84 har jeg her i Landet solgt 19,491 Pd. Røgtobak og 697 Pd. Rapee. Til udenlandske Steder har jeg intet solgt.

Det udenlandske Marked svigtede i 1783-84, og samtidig var det indenlandske Salg kun taget ganske ubetydeligt til. Den efter Tidens Forhold dyre og højt udviklede Drift krævede gode Indtægter. Da disse ikke var tilstrækkelige, rettede Cornelsen i de følgende Aar forskellige Andragender til Kongen om Hjælp. Han sendte bl. a. den 13. Maj 1790 en Ansøgning til Regeringen om et Laan til Udvidelse af sin Tobaksfabrik. Efter Referat i Tyske Journal 1790 hedder det: "Cornelius Cornelsen, Raadmand og Kobmand i Aabenraa, søger Forskud af den $\mathrm{kgl}$. Kasse til Udvidelse af sin Tobaksfabrik paa $10-12,000$ Rbdl. Dette Laan tilbyder han at tilbagebetale i Løbet af 28 Aar. Som Sikkerhed for Kapitalen vil han stille sin Fabrik, Mølle og alt dertil hørende Værktøj, raa og færdige Varer, sit Beboelseshus og Pakhus m. m. og desuden stille Garanti for formaalstjenlig Anvendelse af dette Beløb.«

Den 1. Juni 1790 er der ifølge Tyske Journal givet ham følgende Svar: "Da man ved Fastsættelsen af de Forskrifter, som Hans Majestæt allernaadigst har tilladt og anbefalet $m$. H. $t$. Anvendelsen af Industrifondet ikke har kunnet tage Hensyn til den med en Tobaksiabrik forbundne Industri, og da Commerce-Collegiet ellers ikke raader over noget Fond, hvorfra det ansøgte Laan paa 10-12,000 Rbdl. kan tages, ser man sig ikke i stand til - hvor tilbøjelig dertil man end kunde være - at anbefale Ansøgerens 
ikke ukendte Fabriksvirksomhed og forelagge det under 13. Maj 1790 indsendte Andragende til Undersøgelse paa allerhøjeste Sted."

Cornelsen har ikke ladet sig afskrække, idet der allerede den 7. Juni samme Aar foreligger et nyt Andragende fra ham. Han "gentager sin allerunderdanigste Bøn“ om Laan til at indrette "en Olie- og Sæbemølle efter engelsk Mønster samt et Valseværk til Plattering af det tynde Tobaksdaase Bly."

Heller ikke denne Gang har man kunnet imødekomme hans Andragende. Det tyske Kancellis Kopibog indeholder et under den 17. Juni 1790 afgivet Svar, hvori det bl. a. hedder, at "Finans-Collegiet tilbagesender Raadmand Cornelsens Ansøgning med den Paategning, at man i k k e har kunnet forelægge den for Hans Majestæt til allerhøjeste Bevilling."

Forholdene er efterhaanden blevet endnu mere vanskelige for Cornelsen, og i et Bønskrift af den 13. April 1791 henvender han sig til Statholderen on Hjælp. Han skriver, at han befinder sig i saa haard Nod, at dersom han ikke faar Hjælp til at føre sin Tobaksfabrik videre, vil han gaa konkurs og hans Ejendele blive solgt fra ham. Statholderen sender som Svar herpaa en Skrivelse, dateret Gottorp den 20. April 1791, til Magistraten i Aabenraa, hvori han afslaar Andragendet "til Cornelsens eget bedste".

Det har vel nok været til Cornelsens Fordel, at man fra kapitalstærk Side ikke længer har onsket at sætte flere Penge $i$ hans Tobaksfabrik og Plantage, og det er formentlig ogsaa snart gaaet op for den initiativrige Mand selv, at den danske Tobaksavl ikke havde nogen Fremtid for sig.

Det er kun sparsomme Efterretninger, der efter 1791 foreligger om Cornelsen, men han nævnes i alt 
Fald senere som skibsreder. Som saadan har han dog heller ikke haft Heldet med sig, idet han i Begyndelsen af det 19. Aarhundrede, efter Krigen med Englænderne, mistede alle sine Skibe.

$\overline{-}$ 